October 2002

\title{
Differential Cytoplast Requirement for Embryonic and Somatic Cell Nuclear Transfer in Cattle
}

Fuliang Du

Li-Ying Sung

X Cindy Tian

Xiangzhong Yang

Follow this and additional works at: https://opencommons.uconn.edu/ansc_articles

\section{Recommended Citation}

Du, Fuliang; Sung, Li-Ying; Tian, X Cindy; and Yang, Xiangzhong, "Differential Cytoplast Requirement for Embryonic and Somatic Cell Nuclear Transfer in Cattle" (2002). ANSC Articles. 6.

https://opencommons.uconn.edu/ansc_articles/6 

Nuclear Transfer in Cattle

8 Running Title: Development of cloned embryos from embryonic vs. somatic cells

9 Key Words: oocyte, blastocyst, pre-activation, cloning, reprogramming, development

17 *Correspondence addressed to: Xiangzhong (Jerry) Yang, $\mathrm{PhD}$, Connecticut Center for

18 Regenerative Biology/Department of Animal Science U-4163, University of Connecticut,

191390 Storrs Road, Storrs, CT 06269-4163.

20 Tel: 860-486-2406, Fax: 860-486-0534, E-mail: jyang@canr.uconn.edu 
1 ABSTRACT Effective activation of a recipient oocyte and its compatibility with the

2 nuclear donor are critical to the successful nuclear reprogramming during nuclear

3 transfer. We designed a series of experiments using various activation methods to

4 determine the optimum activation efficiency of bovine oocytes. We then performed

5 nuclear transfer (NT) of embryonic and somatic cells into cytoplasts presumably at G1/S

6 phase (with prior activation) or at metaphase II (M II, without prior activation). Oocytes

7 at $24 \mathrm{~h}$ of maturation in vitro were activated with various combinations of calcium

8 ionophore A23187 (A187) (5 $\mu \mathrm{M}, 5 \mathrm{~min})$, electric pulse (EP), ethanol (7\%, $7 \mathrm{~min})$,

9 cycloheximide (CHX) $(10 \mu \mathrm{g} / \mathrm{ml}, 6 \mathrm{~h})$, and then cultured in cytochalasin D (CD) for a

10 total of $18 \mathrm{~h}$. Through a series of experiments (Expt 1-4), an improved activation

11 protocol (A187/EP/CHX/CD) was identified and used for comparison of NT efficiency of

12 embryonic vs. somatic donor cells (Expt 5). When embryonic cells from morula and

13 blastocysts were used as nuclear donors, a significantly higher rate of blastocyst

14 development from cloned embryos was obtained with G1/S phase cytoplasts than with M

15 II-phase cytoplasts ( $36 \%$ vs. $11 \%, \mathrm{P}<0.05)$. In contrast, when skin fibroblasts were used

16 as donor cells, the use of an M II cytoplast (vs. G1/S phase) was imperative for blastocyst

17 development (30\% vs. $6 \%, \mathrm{P}<0.05)$. Differential staining showed that parthenogenetic,

18 embryonic, and somatic cloned blastocysts contained $26 \%, 29 \%$ and $33 \%$ presumptive

19 inner cell mass (ICM) cells, respectively, which is similar to that of frozen-thawed in vivo

20 embryos at a comparable developmental stage (23\%). These data indicate that embryonic

21 and somatic nuclei require different recipient cytoplast environment for

22 remodeling/reprogramming, and this is likely due to the different cell cycle stage and

23 profiles of molecular differentiation of the transferred donor nuclei. 


\section{INTRODUCTION}

2 Nuclear remodeling/reprogramming represents re-establishment of the totipotency

3 of an introduced nucleus with a progressive pattern of gene expression similar to that

4 occurring during the development of a fertilized embryo. The mechanisms involved in

5 reactivation of the genome from either embryonic or differentiated somatic nucleus

6 during reprogramming remain unclear (Kikyo and Wolffe, 2000; Kühholzer and Prather,

7 2000; Reik et al., 2001; Rideout III et al., 2001). In early nuclear transfer studies

8 conducted in sheep (Willadsen, 1986), cattle (Prather et al., 1987), rabbits (Stice and

9 Robl, 1988), and pigs (Prather et al., 1989), the genome of an embryonic nucleus, was

10 introduced into a metaphase II cytoplasm. Later, studies in sheep demonstrated that the

11 use of recipient cytoplasm at a presumable G1/S phase by pre-activation of the oocyte led

12 to an improved developmental competence of the resultant embryos (Campbell et al.,

13 1994, 1996). This finding was confirmed by several other studies (Stice et al., 1994; Du

14 et al., 1995; Loi et al., 1998; Piotrowaska et al., 2000). More recently, the innovation of

15 somatic cell nuclear transfer has produced live clones in sheep (Wilmut et al., 1997),

16 cattle (Cibelli et al., 1998; Kato et al., 1998; Wells et al., 1999; Hill et al., 2000; Kubota

17 et al., 2000), mice (Wakayama et al., 1998), goats (Baguisi et al., 1999, Zou et al., 2001,

18 Keefer et al., 2002), pigs (Betthauser et al., 2000; Onishi et al., 2000; Polejaeva et al.,

19 2000), cat (Shin et al., 2002) and rabbits (Chesne et al., 2002). In most of these cases, the

20 nucleus from highly differentiated $\mathrm{G}_{\mathrm{o}}$ cell or active dividing cell (G1) was transferred

21 into a metaphase II oocyte. No efforts have been made, however, to directly compare the

22 developmental competence of embryos cloned from different donor cells, embryonic vs.

23 adult somatic, and recipient cytoplasts of different activation status, G1/S (pre-activated) 
1 or MII phase. Furthermore, efficient and reliable activation of the recipient oocyte is

2 crucial for competent interaction between a donor nucleus and the recipient cytoplast, and

3 is thought to greatly enhance the efficiency of successful NT (Kono et al., 1994; Stice et

4 al., 1994; Campbell et al., 1996; Wilmut et al, 1997; Wells et al., 1999).

5 In this study we tested a series of combined activation procedures and selected the

6 best protocol for subsequent nuclear transfer using embryonic and somatic cells as

7 nuclear donors. We report here that while pre-activated cytoplasts are beneficial for

8 embryonic nuclear transfer, M II cytoplasts are essential for somatic cell nuclear transfer.

MATERIALS AND METHODS

Media and Chemicals

11 Basic culture was in Medium 199 (M199) with Earle's salts, L-glutamine, $2.2 \mathrm{~g} / 1$

12 sodium bicarbonate, and $25 \mathrm{mM}$ HEPES (Gibco, 12340-014) containing 7.5\% (v/v) fetal

13 calf serum (Gibco, 26140-012) (M199+FCS). Maturation medium consisted of

14 M199+FCS supplemented with $0.5 \mu \mathrm{g} / \mathrm{ml}$ ovine FSH, $5.0 \mu \mathrm{g} / \mathrm{ml}$ ovine LH (NIDDK) and

$15 \quad 1.0 \mu \mathrm{g} / \mathrm{ml}$ estradiol (Sigma, E-8875). The media utilized for washing ovaries and oocytes

16 consisted of Dulbecco's phosphate buffered saline (D-PBS; Gibco, 15240-013)

17 containing 0.1\% polyvinyl alcohol (PVA; Sigma, P-8136) (D-PBS+PVA). Calcium free

18 D-PBS+PVA was used for preparing 0.2\% hyaluronidase (Sigma, H-3506) solution in

19 addition to some activation solutions. Activation solutions were as follows: $5 \mu \mathrm{M}$

20 calcium ionophore A23187 (A187) (Sigma, C-7522), 7\% ethanol in calcium free D-PBS-

21 PVA (ETOH), and $10 \mu \mathrm{g} / \mathrm{ml}$ cycloheximide (CHX) (Sigma, C-6255) in M199+FCS.

22 Electric-pulse (EP) treatment medium consisted of $0.3 \mathrm{M}$ mannitol, $0.05 \mathrm{mM} \mathrm{CaCl}_{2}, 0.1$

$23 \mathrm{mM} \mathrm{MgSO}_{4}$ and $0.5 \mathrm{mg} / \mathrm{ml}$ bovine serum albumin (BSA) (Fraction V, Sigma, A-9647). 
1 Cytochalasin B (CB) (Sigma, C-6762) at concentrations of 2.5, 5, $7.5 \mu \mathrm{g} / \mathrm{ml}$, and

2 cytochalasin D (CD) (Sigma, C-8273) at $2.5 \mu \mathrm{g} / \mathrm{ml}$ were dissolved in M199+FCS

3 depending on the experimental design. Frozen embryos were thawed by a stepwise

4 procedure in: a) D-PBS with $0.4 \% \mathrm{BSA}, 6 \%$ glycerol and $0.3 \mathrm{M}$ sucrose, b) D-PBS with

$5 \quad 0.4 \% \mathrm{BSA}, 3 \%$ glycerol and $0.3 \mathrm{M}$ sucrose, c) D-PBS with $0.4 \% \mathrm{BSA}$ and $0.3 \mathrm{M}$ sucrose,

6 and d) $0.4 \%$ BSA in D-PBS for 5 min each. The zona pellucida of the donor embryos

7 were removed by acidic D-PBS (pH 2.3) and 0.5\% pronase (Sigma, P-6911) in M199.

8 The solution to desegregate embryonic blastomeres was $0.25 \%$ trypsin (Sigma, T-0646)

9 in Hank's balanced salt solution (HBSS; Gibco, 450-1250EB). Micromanipulation

10 medium for enucleation and donor cell transfer was M199+FCS containing $7.5 \mu \mathrm{g} / \mathrm{ml}$

11 CB. Skin fibroblast cells were cultured in Dulbecco's Minimum Eagle's medium

12 (DMEM; Gibco, 31600) supplemented with 10\% FBS (Hyclone, SH0070.03) and

13 antibiotics (Gibco, 15240-013) at $37^{\circ} \mathrm{C}$ in $5 \% \mathrm{CO}_{2}$ humidified air. Medium M2,

14 containing $4 \mathrm{mg} / \mathrm{ml}$ BSA was the basic solution for differential staining. Before staining,

15 the following chemicals and solutions were prepared: $10 \mathrm{mM} \mathrm{2,4,6-}$

16 Trinitrobenzenesulfonic acid (TNBS) (Sigma, P-2297), $0.1 \mathrm{mg} / \mathrm{ml}$ anti-DNP-BSA (ICN,

17 610006-1), specified concentration of guinea pig complement (Sigma, S-1639), 2.5

$18 \mathrm{mg} / \mathrm{ml}$ propidium iodide (PI; Sigma, P-4170), and $5 \mu \mathrm{g} / \mathrm{ml}$ Hoechst 33258 (Sigma, B-

19 2883).

\section{Oocyte Maturation In Vitro, Selection and Activation}

21 Oocytes used in this study were aspirated from antral follicles of slaughterhouse

22 ovaries as described previously (Yang et al., 1993). Oocytes with at least 4 layers of

23 cumulus cells were selected, washed three times in D-PBS+PVA, one time in maturation 
1 medium, and then cultured for $20-22 \mathrm{~h}$ in $5 \% \mathrm{CO}_{2}$ and $95 \%$ humidified air at $39{ }^{\circ} \mathrm{C}$.

2 Cumulus cells were then stripped from the oocytes by 5 min of incubation in $0.2 \%$

3 hyaluronidase and 1.5 min vigorous vortexing. Denuded oocytes with a polar body were

4 selected and randomly allocated to various activation or enucleation treatments.

5 In a series of activation studies different repetitive and combined activation

6 protocols were compared according to the experimental design detailed below. Briefly,

7 oocytes were activated by various activation procedures beginning at $24 \mathrm{~h}$ post

8 maturation (hpm). Activation stimuli included A23187, $5 \mu \mathrm{M}$ for $5 \mathrm{~min} ; \mathrm{EP}, 1.2 \mathrm{kV} / \mathrm{cm}$,

9 for $30 \mu \mathrm{sec}$ unless indicated otherwise; CHX $10 \mu \mathrm{g} / \mathrm{ml}$ in M199-FCS for $6 \mathrm{~h}(24-30$

$10 \mathrm{hpm}$ ), and subsequently 2.5 or $5 \mu \mathrm{g} / \mathrm{ml} \mathrm{CB}$ or $2.5 \mu \mathrm{g} / \mathrm{ml} \mathrm{CD}$ in M199-FCS for $18 \mathrm{~h}$ (24-

$11 \quad 42 \mathrm{hpm})$.

Donor embryos and embryonic cell isolation for nuclear transfer

13 Embryonic donor cells for NT were derived from frozen embryos produced in

14 vivo at late morulae and early blastocyst stage. Embryos were thawed at $21-27^{\circ} \mathrm{C}$ in air

15 for $10 \mathrm{sec}$, then in a $27^{\circ} \mathrm{C}$ water bath for less than $10 \mathrm{sec}$. Glycerol was removed in four

16 steps of 5 min each by systematically pre-washing with the thawing solutions described

17 above with decreasing concentrations of glycerol. The thawed embryos were then

18 transferred into M199-FCS and cultured for 30-45 min.

19 After removal of the zona pellucida, embryos were incubated for 2-3 min in cell

20 disaggregating solution and gently pipetted with a fine, fire-polished capillary pipette in

21 M199+FCS until individual cells were disaggregated. Isolated cells had diverse

22 morphology, and only the small, round-shaped and healthy looking cells were selected

23 for NT. 


\section{Adult fibroblast cell culture and donor cell preparation}

2 Skin explants taken from the ear of Aspen, a 13-year-old dairy cow with a high

3 milk yield from the University of Connecticut's herd, were cultured in Falcon 35x10 mm

4 culture dishes (Becton Dickinson, 3001) with 10\% FBS DMEM at $37^{\circ} \mathrm{C}$ in $5 \% \mathrm{CO}_{2}$

5 humidified air. Fibroblast monolayers formed around the tissue explants in about two

6 weeks. The explants were then removed and placed into new culture dishes. Cultures of

7 the fibroblasts were continued until confluency was reached. For passaging, cells were

8 washed with $1 \mathrm{ml}$ of Dulbecco's PBS, then gently digested by a three-minute incubation

9 in $250 \mu \mathrm{l} 0.05 \%$ trypsin (ICN, 103140) and $0.5 \mathrm{mM}$ EDTA (Baker, 8991) at $37^{\circ} \mathrm{C}$. The

10 reaction was terminated by adding 10\% FBS in DMEM. Subsequently, the cell

11 suspension was centrifuged at $1000 \mathrm{rpm}$ for $5 \mathrm{~min}$, and cells were then resuspended and

12 divided into three new dishes and maintained for 6-7 days. Cells cultured to different

13 passages were collected and frozen in 10\% dimethylsulfoxide DMSO (Sigma, D5879) at

$14-80{ }^{\circ} \mathrm{C}$ and stored in liquid nitrogen.

15 In this study fibroblast cells at passage 5 or 6 were used for nuclear transfer.

16 Briefly, after reaching confluency, donor cells were serum starved in 0.5\% FBS DMEM

17 for 4-5 days. Cells were then disassociated by 2-3 min of trypsinization at $37^{\circ} \mathrm{C}$, and

18 resuspended in $0.5 \%$ FBS in DMEM. Finally, cell suspensions were allowed to recover

19 for about $45 \mathrm{~min}$ at $37^{\circ} \mathrm{C}$ before nuclear transfer.

20 Culture and evaluation of parthenogenetic and cloned embryos in vitro

21 Activated oocytes and nuclear transferred embryos were cultured in M199

22 medium supplemented with 7.5\% FBS for 8 days (initiation of activation $=$ day 0 ) on

23 buffalo rat liver cell (BRLC) monolayers. Cleavage and blastocyst development rates 
1 were recorded on Day 3 and Day 8, respectively. The cell number of the blastocysts was

2 evaluated either by fluorescent microscopy following staining with $10 \mu \mathrm{g} / \mathrm{ml}$ Hoechst

333342 , or by differential staining described below.

4

$8 \mathrm{CHX}$ for $6 \mathrm{~h}$, followed by two electric pulses (EP) 30 min apart at $31 \mathrm{hpm}$

9 (A187/EP/CHX/EPx2). In Treatment B oocytes were stimulated as for Treatment A 10 except that EP stimulation was given at $24 \mathrm{hpm}$ instead of A187 (EP/EP/CHX/EPx2). In

11 Treatment C, oocytes were activated with EP at $24 \mathrm{hpm}, \mathrm{ETOH}$ at $25 \mathrm{hpm}$, followed by

12 the same procedures as for treatments $\mathrm{A}$ and $\mathrm{B}(\mathrm{EP} / \mathrm{ETOH} / \mathrm{CHX} / \mathrm{EP} 2)$. In Treatment $\mathrm{D}$, 13 oocytes were treated with A23187 at $24 \mathrm{hpm}, \mathrm{EP}, 1.0 \mathrm{kV} / \mathrm{cm}, 90 \mu \mathrm{sec}$ at $25 \mathrm{hpm}$, CHX 14 for $6 \mathrm{~h}$ and $\mathrm{CD}$ for $18 \mathrm{~h}(\mathrm{~A} 187 / \mathrm{EP} 90 / \mathrm{CHX} / \mathrm{CD})$. Treatment $\mathrm{E}$ was a non-stimulation 15 control (Table 1).

\section{Experiment 2. Comparison of electric pulses}

Five treatments were designed to examine the effect of the intensity and duration of electric pulses on embryonic development of activated oocytes. Oocytes in Treatment D (A187/EP90/CHX/CD) were handled as in Treatment D in Exp. 1, while oocytes in treatments A, B, and C were activated as in Treatment D except for the EP stimulus being

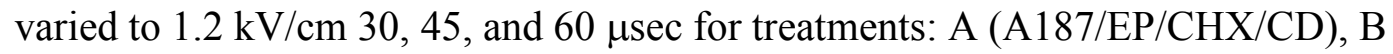
(A187/EP45/CHX/CD) and C (A187/EP60/CHX/CD), respectively. Treatment E was conducted as for Treatment A but without CD incubation (A187/EP/CHX) (Table 2). 


\section{Experiment 3. Effect of cytochalasins on parthenogenetic development}

Treatments A, B, and C were the same as in Treatment A of Exp. 1. However, the oocytes were incubated for $18 \mathrm{~h}$ in $2.5 \mu \mathrm{g} / \mathrm{ml}$ cytochalasin B (CB) (A, A187/EP/CHX/CB2.5/EPx2), $5 \mu \mathrm{g} / \mathrm{ml} \mathrm{CB} \mathrm{(B,} \mathrm{A187/EP/CHX/CB5/EPx2)} \mathrm{and} 2.5 \mu \mathrm{g} / \mathrm{ml}$ cytochalasin D (CD) (C, A187/EP/CHX/CD/EPx2), respectively. Treatment D was the same as for Treatment D in Exp.1 (A187/EP90/CHX/CD) (Table 3).

\section{Experiment 4. Effect of fusion pulses on parthenogenetic development}

In previous studies, we had found that two EPs (30 min apart) at $31 \mathrm{hpm} \mathrm{had}$ enhanced the membrane fusion and development of NT embryos (Du et al., 1995). We, therefore, directly compared whether there was a difference between in vitro development of activated oocytes from Treatment $\mathrm{C}$ in Exp. 3 (A187/EP/CHX/CD/EPx2), and Treatment A in Exp. 2 (A187/EP/CHX/CD). Experiment 5. NT with metaphase II (MII) and pre-activated (G1/S) cytoplasts Recipient oocyte enucleation was conducted in M199+FCS containing $7.5 \mu \mathrm{g} / \mathrm{ml}$ $\mathrm{CB}$ at $22 \mathrm{hpm}$ by aspiration of the first polar body and its surrounding cytoplasm, $\sim 1 / 8$ total oocyte volume. Successful enucleation was confirmed by fluorescent microscopy after staining with $10 \mu \mathrm{g} / \mathrm{ml}$ Hoechst 33342. For activation prior to NT, enucleated oocytes were activated with the optimal procedure as determined from previous experiments (A187/EP/CHX) from 24 to $30 \mathrm{hpm}$ that induced pre-activated $\mathrm{G} 1 / \mathrm{S}$ cytoplasts. Embryonic donor cell insertion was completed during 30-31 hpm and membrane fusion was induced at $31 \mathrm{hpm}$ with two EPs $(1.2 \mathrm{kV} / \mathrm{cm}, 30 \mu \mathrm{sec}) 30 \mathrm{~min}$. apart. In the case of NT into MII cytoplasts, donor cells were transferred at $24 \mathrm{hpm}$, and electric fusion was completed by about $25 \mathrm{hpm}$. After the second electric pulse, oocyte- 
1 donor cell complexes were incubated for $15-30 \mathrm{~min}$ in 20\% FBS in PBS at room

2 temperature before being subjected to further activation procedures (A187/EP/CHX)

3 between 25 and $31 \mathrm{hpm}$. Fusion rates were determined $90 \mathrm{~min}$ after the first fusion pulse.

4 Following activation the fused embryos were cultured in M199+FCS on BRLC

5 monolayers (Rehman et al., 1994).

6 In NT with embryonic cells, Treatment A was NT into pre-activated cytoplasts

7 (A187/EP/CHX/NT) while Treatment B was NT into a cytoplast without prior activation

8 (MII/NT/A187/EP/CHX) (Table 5).

9 When somatic nuclei from skin fibroblasts were used as the donors, NT with pre-

10 activated (Treatment C) and metaphase II (Treatment D) cytoplasts was completed as

11 described above (Table 5). Small donor cells with an approximate diameter of 12-15 $\mu \mathrm{m}$

12 were allocated for transfer into the perivitelline space of enucleated oocytes (Vignon et

13 al., 1998). Somatic donor cell-cytoplasm pairs were fused by applying two direct current

14 pulses at $2.0 \mathrm{kV} / \mathrm{cm}$ for a duration of $10 \mu \mathrm{sec} / \mathrm{each}$ pulse. Following the completion of

15 electric fusion, there was also an 15 min incubation at room temperature before activation

16 with the optimal regime of A187/EP/CHX was applied.

\section{Differential staining}

18 Embryos were allowed to develop to Day 8. Early blastocysts (BL), regular BL,

19 expanded $\mathrm{BL}$ and hatched $\mathrm{BL}$ were harvested from parthenogenetic, cloned and in vivo

20 produced embryos. Expanded and hatched BLs were subjected to differential staining.

21 After removal of the zona pellucida, embryos were treated with $10 \mathrm{mM}$ TNBS for $10 \mathrm{~min}$

22 at $4^{\circ} \mathrm{C}$, washed 3 times in $\mathrm{M}_{2}$-BSA and incubated in $0.1 \mathrm{mg} / \mathrm{ml}$ anti-DNP-BSA for 10

23 min at $39^{\circ} \mathrm{C}$, washed in $\mathrm{M}_{2}-\mathrm{BSA}$ again to remove surplus antibody, then treated by a 12 
1 min incubation with guinea pig complement solution and $0.25 \mathrm{mg} / \mathrm{ml}$ propidium iodide.

2 The embryos were then stained with $0.5 \mathrm{mg} / \mathrm{ml}$ Hoechst 33258 in ethanol for at least $1 \mathrm{~h}$

3 to distinguish presumptive inner cell mass (ICM) whose nuclei stained blue. Presumptive

4 trophectoderm (TE) cells were stained by both propidium and Hoechst 33258, and

5 differentially indicated by a pink stain. Embryos were mounted and gently squashed

6 under a cover slip for counting of nuclei under fluorescent microscopy.

9 from various treatments within each experiment were analyzed by Chi-square (Snedecor

10 and Cochran, 1980) or student's t-test. The mean number of nuclei for each embryo was

11 compared by one-way ANOVA. The $\mathrm{P}$ values less than 0.05 are considered as significant 12 between the treatments.

\section{Statistical Analyses}

Proportions of embryos reaching cleavage and developing to the blastocyst stage between the treatnents.

\section{RESULTS}

\section{Experiment 1}

After in vitro maturation of oocytes for $20 \mathrm{~h}$, cumulus cells had expanded as shown in Fig 1.A. Following parthenogenetic activation, oocytes usually cleaved to the 4-8 cell stage at 44-48 $\mathrm{hr}$ of in vitro culture, and further developed to compacted morula (Fig 1.B) on Day 4, and to expanding blastocysts (Fig 1.C) on Day 8 in accordance to the developmental pace expected for in vitro fertilized embryos. The proportion of degenerated oocytes following activation in Treatments B (27\%), and D (38\%) were significantly higher than in Treatments A (4\%), C (4\%) and control E (0\%) $(\mathrm{P}<0.05)$. Oocyte degeneration frequently took place before two electric pulses were applied at 31 hpm. Among the survived oocytes in Treatments A, B, C, and D, the oocytes with good 
1 quality were selected for continuous in vitro culture. There was no difference among

2 Treatments A, B, or C in terms of cleavage and blastocyst development after culture in

3 vitro, and no difference among Treatment $\mathrm{A}, \mathrm{B}, \mathrm{C}$, and $\mathrm{D}$ for the overall rate of blastocyst

4 development (Table 1). Despite the high percentage of oocyte lysis in Treatment D when

5 compared to Treatments A, B and C, a significant higher rate of cleavage to 2-8 cells

$6 \quad(74 \%$ vs. $42-53 \%, P<0.05)$ and subsequent embryonic development to blastocyst stage

7 (31\% vs. 8-14\%, $\mathrm{P}<0.05)$ (Table 1) were observed. In the control group (Treatment E),

$8 \quad 11 \%$ of oocytes underwent spontaneous activation and cleavage to the 2-8 cell stage, but

9 no further development was observed. Thereafter, experiments were specifically

10 designed to determine whether the higher degree of oocyte lysis was due to the duration

11 of the EP and cytochalasin incubation (Exp.2), or if the development was improved by

12 the cytochalasin treatment (Exp. 3).

\section{Experiment 2}

14 This experiment was designed to test if a longer duration of electrical pulse

15 resulted in a significantly higher incidence of oocyte lysis. As shown in Table 2, when

$161.2 \mathrm{kV} / \mathrm{cm}$ was applied and the duration was increased from $30 \mu \mathrm{sec}$ in Treatment A to 45

$17 \mu$ sec in Treatment B, $11 \%$ and $17 \%$, respectively, of the oocytes were lysed, while $28 \%$

18 in Treatment $\mathrm{C}$ were degenerated after subjected to a pulse of $1.2 \mathrm{kV} / \mathrm{cm}$ for $60 \mu \mathrm{sec}$,

19 significantly higher than Treatments A and $\mathrm{B}(\mathrm{P}<0.05)$. When the duration of the pulse

$20(1.0 \mathrm{kV} / \mathrm{cm})$ was increased to $90 \mu \mathrm{sec}$ in Treatment $\mathrm{D}$, up to $42 \%$ of the oocytes were

21 completely lysed, significantly higher than Treatments A, B and C $(\mathrm{P}<0.05)$. In contrast

22 to other groups, Treatment E, in which oocytes were activated as for Treatment A but

23 without cytochalasin D incubation, represented the lowest lysis (2\%), significantly lower 
1 than Treatments A, B, C and D $(\mathrm{P}<0.05)$. The overall blastocyst development varied

2 from 22 to $29 \%$ in Treatments A and B, which was significantly higher than Treatments

3 D and E. The highest rate of development (29\%) was achieved in Treatment A that was

4 significantly higher than Treatments C, D and E (Table 2). We concluded, therefore, that

5 oocyte lysis was caused by both prolonged exposure to electric pulse and culture with

6 cytochalasin D. Interestingly, the cleavage and blastocyst development of oocytes in

7 Treatments A, B, C and D were not different from each other. These values, however,

8 were significantly higher than those in Treatment $\mathrm{E}(\mathrm{P}<0.05)$, indicating the beneficial

9 effect of cytochalasin D on the development of parthenogenetic oocytes.

\section{Experiment 3}

11 From the results of Exp. 2, Treatment A (least oocyte lysis) was selected to

12 determine the effect of cytochalasins on embryo development (Table 3). There was no

13 difference in the extent of cell lysis between Treatments $A$ to $C$ with various

14 concentrations of cytochalasin D or cytochalasin B (A: 15\%; B: 14\%; C: 12\%; P>0.05).

15 A significantly higher rate of oocyte lysis was found in Treatment $\mathrm{D}(53 \%, \mathrm{P}<0.05)$.

16 However, live parthenogenetic oocytes showed similar cleavage rates and blastocyst

17 development among Treatments $\mathrm{A}$ and $\mathrm{B}(\mathrm{P}>0.05)$. In contrast, oocytes in Treatment $\mathrm{C}$

18 gave rise to $38 \%$ blastocyst development, better than any cytochalasin B treatments

19 although there was no difference between the cytochalasin D groups. The overall

20 efficiency of blastocyst development in Treatment $\mathrm{C}$ was $26 \%$ when all oocytes used

21 were taken into consideration and this is the highest among all treatments (Table 3). As a

22 result, Treatment C in Exp.3 was selected as the optimal regime to parthenogenetically

23 activate bovine oocytes in the next series of experiments. 
13 When the donor nuclei were embryonic cells (Fig 1, E to G), pre-activation of recipient

14 cytoplasts (Treatment A, Fig 1, F) significantly improved the cloned embryo's ability to

15 undergo cleavage (77\% vs. 50\%, P<0.05) and blastocyst (Fig 1, G) development (36\%

16 vs. $11 \%, \mathrm{P}<0.01$ ) as compared to NT into M II cytoplasm (Table 4). Interestingly,

17 enucleated oocytes without transfer of donor nuclei can also undergo parthenogenetic

18 development. Some cytoplasts could finish several cell divisions developing to the 8-cell

19 stage before degenerating (data not shown). In contrast, when NT was conducted with

20 cultured somatic cells as donors (Fig 1, I), metaphase phase (MII) recipient cytoplasm

21 (Fig 1, J) greatly enhanced the extent to which early embryos cleaved (Fig 1, K) (76\% vs.

$2258 \%, \mathrm{P}<0.05)$ or developed to blastocysts ( $30 \%$ vs. $6 \%, \mathrm{P}<0.05)$.

\section{Analysis of Cell Allocations to TE or ICM}


As shown in Table 5, following embryo immunosurgery and differential staining,

2 the total number of nuclei in expanded or hatching blastocysts between parthenogenetic

3 (Fig 1, C, D) and NT (Fig 1, G, H) groups was not significantly different (Table 5). The

4 proportion of ICM in different types of blastocysts was not significantly different for

5 embryonic NT, somatic NT, parthenogenetic and frozen in vivo derived embryos, shown

6 as $29 \%, 33 \%, 26 \%$ and $23 \%$, respectively. Cloned blastocysts developed from an

7 activated cytoplast and an embryonic nucleus (Fig 1, G, H), or from an MII cytoplast and

8 a somatic nucleus (Fig 1, K, L) showed a similar total cell number and ICM/TE ratio.

9 There was also no difference between NT and parthenogenetic hatched embryos with

10 respect to the percentage of pycnotic cells. However, some parthenogenetic embryos

11 were observed with a sporadic and dislocated distribution of ICM cells $(58 \%, \mathrm{n}=38)$ and

12 an apparent variation in nuclear volume ranging from less to more than the average of the

13 group $(45 \%, \mathrm{n}=38)$.

\section{DISCUSSION}

15 In the present study, we compared various activation protocols and showed that

16 the development of cloned embryos reconstructed from either embryonic or somatic

17 nuclei require cytoplasts in different activation status for optimal development. In our

18 study with embryonic donor nuclei, nuclear transfer into pre-activated oocytes resulted in

19 a high percentage, $36 \%$, of blastocysts, while only $11 \%$ of embryos without prior

20 activation developed blastocysts. During early development, the embryonic cells divide

21 very rapidly and mitosis is relatively short. The interphase of cell cycle in most

22 embryonic cells in pre-implantation embryos of mice, sheep and cattle is notably

23 occupied by S phase (Collas et al., 1993, Campbell et al., 1994). After fusion between an 
$1 \quad$ S phase cell and an metaphase cell (Johnson and Rao, 1970), active maturation promoting

2 factor (MPF) in the metaphase cell or oocyte initiates nuclear envelope breakdown

3 (NEBD) and premature chromosome condensed (PCC), resulting in a pulverized

4 chromatin appearance (Sperling and Rao, 1974; Szöllösi et al., 1988; Barnes et al.,

5 1993). Pulverized PCC may cause the breakage of chromatin and the damage to DNA

6 duplexes in donor nuclei. Therefore, it is essential to synchronize the recipient oocyte

7 and the S phase nucleus during nuclear transfer. Activation of cytoplasts prior to nuclear

8 transfer makes the recipient oocyte transit from MII to G1/S phase, resulting in a

9 universal cytoplasm for the donor nucleus, and allowing continuous DNA synthesis to

10 occur in the S phase donor nucleus (Campbell et al., 1994, 1996). Although transplanting

11 blastomere nuclei into M II cytoplasts has produced full term development in sheep

12 (Willadsen, 1986), rabbits (Stice and Robl, 1988), cattle (Prather et al., 1987), and pigs

13 (Prather et al., 1989), nuclear-cytoplasm synchronization in embryonic cell nuclear

14 transfer increases the developmental efficiency of the reconstructed embryos (Collas et

15 al., 1993; Campbell et al., 1994; Kono et al., 1994). Recently, prior activation of

16 recipient oocytes resulted in successful nuclear transfer of embryonic cells in cattle

17 (Kubota et al., 1998), Rhesus monkeys (Meng et al., 1997) and rabbits (Piotrowaska et

18 al., 2000).

19 Alternatively, nuclear transfer with differentiated skin cells and M II cytoplasts

20 yielded significantly higher early development when compared to those transferred into

21 pre-activated recipient cytoplasts. In our study, cultured skin fibroblasts were serum

22 starved for 4-5 days, and were thus synchronized at $\mathrm{G}_{\mathrm{o}} / \mathrm{G} 1$ phase (Kubota et al., 2000).

23 An M phase cell induces the G1 nucleus into a pattern of PCC with intact single 
1 chromatids (Sperling and Rao, 1974). During somatic nuclear transfer, this chromatin

2 modification due to NEBD and PCC by the MII cytoplast may facilitate the course of

3 reprogramming of differentiated nucleus such as an epithelial cell (Wilmut et al., 1997),

4 cumulus cell (Kato et al., 1998) adult mural granulosa cell (Wells et al., 1999), and skin

5 fibroblast (Hill et al., 2000; Kubota et al., 2000). It is possible that certain degrees of

6 PCC can induce chromatin rearrangement in the donor nucleus that facilitates the process

7 of demethylation of the highly methylated genome. It is unclear, however, that the

8 minimum time somatic nucleus should be exposed to a high level of MPF in the cytoplast

9 for complete nuclear reprogramming (Wilmut et al., 1997; Wakayama et al., 1998; 1999).

10 Wells et al. (1999) demonstrated that exposure of a quiescent nucleus to enucleated MII

11 cytoplast for $4-6 \mathrm{~h}$ before activation resulted in an increased proportion (up to $27.5 \%$ ) of

12 fused embryos developing into blastocysts. Similarly, nuclei introduced either by electric

13 fusion in cattle (Cibelli et al., 1998; Wells et al., 1998) or direct nuclear injection in pigs

14 (Onishi et al., 2000) were subjected to a 2-6 hour exposure to MII cytoplast before

15 activation. In our study, however, a 30\% blastocyst development was obtained when

16 oocyte-donor cell complexes were activated no longer than 15 min after cell fusion.

17 When cumulus cells from the same donor animal were used with the same timing of

18 activation, as high as $50 \%$ blastocysts development was achieved (data not shown).

19 Recently, short exposure of somatic nuclei from a genetically modified fetal cell line in

20 MII cytoplasts resulted in cloned blastocysts that produced pregnancies ( $\mathrm{Du}$ and Yang,

21 2002, unpublished data). Further experiments will be of interest to determine the

22 minimum period of exposure necessary for the complete reprogramming of a

23 differentiated nucleus. 
The factors affecting nuclear reprogramming are mysterious and unclear (Fulka et

2 al., 1998), nevertheless, it is unambiguous that these remodeling factors are uniquely

3 present in the oocyte cytoplasm, and this oocyte reprogramming ability for differentiated

4 somatic nucleus vanishes after pre-activation. Our finding with skin fibroblasts (from a

5 13-year-old cow) as nuclear donors is in accordance with the results of Tani et al. (2001)

6 using cumulus cells. We believe that unknown somatic remodeling factors have a critical

7 impact on the reprogramming of a differentiated nucleus, and on the developmental

8 potential of the fused embryos, however, they appear to be unstable and lose their

9 function after parthenogenetic activation. In contrast, it seems likely that this influence

10 of remodeling factors in the oocyte on the embryonic nucleus is nominal. Donor cells

11 from compacted morula and blastocysts, as those used in our study, are in a state of

12 undifferentiated development, and possess a low degree of methylated genomic DNA

13 (Kühholzer and Prather, 2000; Ridout III et al., 2001). Due to reduced DNA methylation,

14 cloned embryos derived from embryonic nuclei will share similar processes with ES cell-

15 derived clones that may need little or no reprogramming of genes for early development

16 (Ridout III et al., 2001). Therefore, we assume that the differentiation state of a

17 transplanted donor karyoplast may have some influence over the extent of its

18 reprogramming. In other words, remodeling of a donor genome by a recipient oocyte is

19 dependent upon the molecular differentiation existed in this nucleus, such as methylation,

20 one of the major differentiation events and epigenetic modifications of the genome during

21 mammalian development (Reik et al; 2001).

22 The efficiency of combined activation could still be improved to further increase

23 nuclear transfer efficiency. In the present study, we have shown that in vitro matured 
1 bovine oocytes can be effectively activated and as many as $40 \%$ of them can undergo

2 further parthenogenetic development to blastocysts (Expt 1-4). The optimal

3 parthenogenetic activation procedure is a combined treatment of $5 \mu \mathrm{M} \mathrm{A} 23187$ for 5 min

4 at $24 \mathrm{hpm}, 1.2 \mathrm{kV} / \mathrm{cm}$ of EP for $30 \mu \mathrm{sec} 1 \mathrm{hr}$ later, $10 \mu \mathrm{g} / \mathrm{ml}$ cycloheximide for $6 \mathrm{~h}(24-42$

$5 \mathrm{hpm}$ ) in addition to culture in $2.5 \mu \mathrm{g} / \mathrm{ml}$ cytochalasin D (A187/EP/CHX/CD). The

6 synergistic effects of repetitive and combined activation treatments cause destruction of

7 existing MPF and prevents further synthesis of new MPF in the oocytes. The commonly

8 used activation reagents/stimuli are broad-spectrum modulators of calcium concentration

9 (Cuthberston, 1981; Ware et al., 1992; Stice et al., 1994), inhibitors of protein synthesis

10 (Presicce and Yang, 1994; Piotrowska et al., 2000) and phosphorylation (Susko-Parrish et

11 al., 1994; Loi et al., 1998). In addition, the detrimental effects of high intensity electric

12 shock is possibly attributed to damage to the oocyte's membrane and cytoplasmic

13 components (Zimmerman and Vienken, 1982). Cytochalasins are microfilament

14 inhibitors and serve to suppress the extrusion of the second polar body, which sustain the

15 diploid state of the activated oocytes. Our study confirms the observation that both

16 cytochalasins B (Kono et al., 1989, Fukui et al., 1992) and D (Minamihashi et al., 1993)

17 improve parthenogenetic development. It makes no doubt that the development of

18 reagents specific for modulations of proteins involved in oocyte activation will greatly

19 improve the nuclear transfer efficiency.

20 In the present study, we found that parthenogenetically activated and NT

21 blastocysts have similar TE and ICM cells to those in frozen in vivo embryos, but both

22 parthenogenetic and cloned embryos had reduced total cell numbers, as well as ICM

23 numbers, when compared to those of in vivo produced embryos (Du and Yang, 
1 unpublished data). It is unknown whether the lower number of cells in the cloned

2 embryos was a result of nuclear reprogramming or was due to the developmental

3 potential of the parthenogenetically activated recipient cytoplasts.

4 In conclusion, more effective activation and parthenogenetic development in

5 cattle was achieved with a combination treatment consisting of calcium ionophore,

6 electric pulse and cycloheximide. Higher in vitro development was achieved when

7 embryonic and somatic donor cells were transferred into pre-activated and MII

8 cytoplasts, respectively.

9

10 
2 Baguisi A, Behboodi E, Melican DT, Pollock JS, Destrempes MM, Cammuso C,

3 Williams JL, Nims SD, Porter CA, Midura P, Palacios MJ, Ayres SL, Denniston RS,

4 Hayes ML, Ziomek CA, Meade HM, Godke RA, Gavin WG, Overstrom EW,

5 Echelard Y. 1999. Production of goats by somatic cell nuclear transfer. Nat

$6 \quad$ Biotechnol 17:456-461.

7 Barnes FL, Collas P, Powell R, King WA, Westhusin M, Shepherd D. 1993. Influence of

8 recipient oocyte cell cycle phase on DNA synthesis, nuclear envelope breakdown,

9 chromosome constitution, and development in nuclear transplant bovine embryos.

$10 \quad$ Mol Reprod Dev 36:33-41.

11 Betthauser J, Forsberg E, Augenstein M, Childs L, Eilertsen K, Enos J, Forsythe T,

12 Golueke P, Jurgella G, Koppang R, Lesmeister T, Mallon K, Mell G, Misica P, Pace

13 M, Pfister-Genskow M, Strelchenko N, Voelker G, Watt S, Thompson S, Bishop M.

14 2000. Production of cloned pigs from in vitro systems. Nat Biotechnol 18:1055-1059.

15 Campbell KH, Loi P, Cappai P, Wilmut I. 1994. Improved development to blastocyst of

16 ovine nuclear transfer embryos reconstructed during the presumptive S-phase of

17 enucleated activated oocytes. Biol Reprod 50:1385-1393.

18 Campbell KH, Loi P, Otaegui PJ, Wilmut I. 1996. Cell cycle co-ordination in embryo

19 cloning by nuclear transfer. Rev Reprod 1:40-46.

20 Chesne P, Adenot PG, Viglietta C, Baratte M, Boulanger L, Renard JP. 2002. Cloned

21 rabbits produced by nuclear transfer from adult somatic cells. Nat Biotechnol 20:36622369. 
1 Cibelli JB, Stice SL, Golueke PJ, Kane JJ, Jerry J, Blackwell C, Ponce de Leon FA, Robl

2 JM. 1998. Cloned transgenic calves produced from nonquiescent fetal fibroblasts.

3 Science $280: 1256-1258$.

4 Collas P, Fissore R, Robl JM, Sullivan EJ, Barnes FL. 1993. Electrically induced calcium

5 elevation, activation, and parthenogenetic development of bovine oocytes. Mol Reprod

6 Dev 34:212-223.

7 Cuthbertson KS. 1983. Parthenogenetic activation of mouse oocytes in vitro with ethanol

8 and benzyl alcohol. J Exp Zool 226:311-314.

9 Du F, Jiang S, Yang X. 1995. Beneficial effect of oocyte activation prior to and during

10 nuclear transfer in cattle using in vitro matured oocytes $24 \mathrm{~h}$ of age. Reprod Nutr Dev

$11 \quad 35: 703-712$.

12 Fukui Y, Sawai K, Furudate M, Sato N, Iwazumi Y, Ohsaki K. 1992. Parthenogenetic

13 development of bovine oocytes treated with ethanol and cytochalasin B after in vitro

14 maturation. Mol Reprod Dev 33:357-362.

15 Fulka J Jr, First NL, Loi P, Moor RM. 1998. Cloning by somatic cell nuclear transfer.

16 Bioessays 20:847-851.

17 Hill JR, Winger QA, Long CR, Looney CR, Thompson JA, Westhusin ME. 2000.

18 Development rates of male bovine nuclear transfer embryos derived from adult and

19 fetal cells. Biol Reprod 62:1135-1140

20 Johnson RT, Rao PN. 1970. Mammalian cell fusion: induction of premature chromosome

21 condensation in interphase nuclei. Nature 226:717-722. 
1 Kato Y, Tani T, Sotomaru Y, Kurokawa K, Kato J, Doguchi H, Yasue H, Tsunoda Y.

2 1998. Eight calves cloned from somatic cells of a single adult. Science 282:2095-

32098.

4 Keefer CL, Keyston R, Lazaris A, Bhatia B, Begin I, Bilodeau AS, Zhou FJ, Kafidi N,

5 Wang B, Baldassarre H, Karatzas CN. 2002. Production of cloned goats after nuclear

6 transfer using adult somatic cells. Biol Reprod 66:199-203.

7 Kikyo N, Wolffe AP. 2000. Reprogramming nuclei: insights from cloning, nuclear

8 transfer and heterokaryons. J Cell Sci 113: 11-20.

9 Kono T, Iwasaki S, and Nakahara T. 1989. Parthenogenetic activation by electric

10 stimulus of bovine oocytes matured in vitro. Theriogenology 32:569-576.

11 Kono T, Sotomaru Y, Aono F, Takahasi T, Ogiwara I, Sekizawa F, Arai T, Nakafara T.

12 1994. Effect of ooplast activation on the development of oocytes following nucleus

13 transfer in cattle. Theriogenology 41:1463-1471.

14 Kubota C, Yang X, Dinnyes A, Todoroki J, Yamakuchi H, Mizoshita K, Inohae S,

15 Tabara N. 1998. In vitro and in vivo survival of frozen-thawed bovine oocytes after

16 IVF, nuclear transfer, and parthenogenetic activation. Mol Reprod Dev 51:281-286.

17 Kubota C, Yamakuchi H, Todoroki J, Mizoshita K, Tabara N, Barber M, Yang X. 2000.

18 Six cloned calves produced from adult fibroblast cells after long-term culture. Proc

$19 \quad$ Natl Acad Sci USA 97:990-995.

20 Kühholzer B, Prather RS. 2000. Advances in livestock nuclear transfer. Proc Soc Exp

$21 \quad$ Biol Med 224: 240- 245.

22 Loi P, Ledda S, Fulka J Jr, Cappai P, Moor RM. 1998. Development of parthenogenetic

23 and cloned ovine embryos: effect of activation protocols. Biol Reprod 58:1177-1187. 
1 Meng L, Ely JJ, Stouffer RL, Wolf DP. 1997. Rhesus monkeys produced by nuclear

$2 \quad$ transfer. Biol Reprod 57:454-459.

3 Minamihashi A, Watson AJ, Watson PH, Church RB, Schultz GA. 1993. Bovine

$4 \quad$ parthenogenetic blastocysts following in vitro maturation and oocyte activation with

$5 \quad$ ethanol. Theriogenology 16:63-67.

6 Onishi A, Iwamoto M, Akita T, Mikawa S, Takeda K, Awata T, Hanada H, Perry AC.

7 2000. Pig cloning by microinjection of fetal fibroblast nuclei. Science 289:1188-

81190.

9 Piotrowska K, Modlinski JA, Korwin-Kossakowski M, Karasiewicz J. 2000. Effects of

10 preactivation of ooplasts or synchronization of blastomere nuclei in G1 on

11 preimplantation development of rabbit serial nuclear transfer embryos. Biol Reprod $12 \quad 63: 677-682$.

13 Polejaeva IA, Chen SH, Vaught TD, Page RL, Mullins J, Ball S, Dai Y, Boone J, Walker

14 S, Ayares DL, Colman A, Campbell KH. 2000. Cloned pigs produced by nuclear

15 transfer from adult somatic cells. Nature 407:86-90.

16 Prather RS, Barnes FL, Sims MM, Robl JM, Eyestone WH, First NL. 1987. Nuclear

17 transplantation in the bovine embryo: assessment of donor nuclei and recipient

18 oocyte. Biol Reprod 37:859-866.

19 Prather RS, Sims MM, First NL. 1989. Nuclear transplantation in early pig embryos. Biol

$20 \quad$ Reprod 41:414-418.

21 Presicce GA, Yang X. 1994. Parthenogenetic development of bovine oocytes matured in

22 vitro for 24 hours and activated by ethanol and cycloheximide. Mol Reprod Dev

$23 \quad 38: 380-385$. 
1 Rehman N, Collins AR, Suh TK, Wright RW, Jr. 1994. Development of in vitro matured

2 and fertilized bovine oocytes co-cultured with buffalo rat liver cells. Theriogenology

$3 \quad 41: 1453-1462$.

4 Reik W, Dean W, Walter J. 2001. Epigenetic reprogramming in mammalian

5 development. Science 293:1089-1098.

6 Rideout III WM, Eggan K, Jaenisch R. 2001. Nuclear cloning and epigenetic

7 reprogramming of the genome. Science 293:1093-1098.

8 Shin T, Kraemer D, Pryor J, Liu L, Rugila J, Howe L, Buck S, Murphy K, Lyons L,

9 Westhusin M. 2002. A cat cloned by nuclear transplantation. Nature 415:859.

10 Snedecor GW, Cochran WG. 1980. Statistical methods (7th ed.). Ames, Iowa: Iowa State

11 University Press, pp 200-208.

12 Sperling K, Rao P. 1974. The phenomenon of premature chromosome condensation: its

13 relevance to basic and applied research. Humangenetik 23:235-258.

14 Stice SL, Robl JM. 1988. Nuclear reprogramming in nuclear transplant rabbit embryos.

15 Biol Reprod 39:657-664.

16 Stice SL, Keefer CL, Matthews L. 1994. Bovine nuclear transfer embryos: oocyte

17 activation prior to blastomere fusion. Mol Reprod Dev 38:61-68.

18 Susko-Parrish JL, Leibfried-Rutledge ML, Northey DL, Schutzkus V, First NL. 1994.

19 Inhibition of protein kinases after an induced calcium transient causes transition of

20 bovine oocytes to embryonic cycles without meiotic completion. Dev Biol 166:729-

$21 \quad 739$. 
1 Szöllösi D, Czołowska R, Szöllösi MS, Tarkowski AK. 1988. Remodeling of mouse

2 thymocyte nuclei depends on the time of their transfer into activated, homologous

3 oocytes. J Cell Sci 91:603-613.

4 Tani T, Kato Y, Tsunoda Y. 2001. Direct exposure of chromosomes to nonactivated

5 ovum cytoplasm is effective for bovine somatic cell nucleus reprogramming. Biol

$6 \quad$ Reprod 64:324-330.

7 Vignon X, Chesne P, Le Bourhis D, Flechon JE, Heyman Y, Renard JP. 1998.

8 Developmental potential of bovine embryos reconstructed from enucleated matured

9 oocytes fused with cultured somatic cells. C R Acad Sci 321:735-745.

10 Wakayama T, Perry AC, Zuccotti M, Johnson KR, Yanagimachi R. 1998. Full-term

11 development of mice from enucleated oocytes injected with cumulus cell nuclei.

$12 \quad$ Nature 394:369-374.

13 Wakayama T, Rodriguez I, Perry AC, Yanagimachi R. Mombaerts P. 1999. Mice cloned

14 from embryonic stem cell. Proc Natl Acad Sci USA 96:14984-14989.

15 Ware CB, Barnes FL, Maiki-Laurila M, First NL. 1989. Age dependence of bovine

16 oocyte activation. Gamete Res 109:117-127.

17 Wells DN, Misica PM, McMillian WH, Tervit HR.1998. Production of cloned bovine

18 fetuses following nuclear transfer with cells from a fetal fibroblast cell line.

19 Theriogenology 49:330.

20 Wells DN, Misica PM, Tervit HR. 1999. Production of cloned calves following nuclear

21 transfer with cultured adult mural granulosa cells. Biol Reprod 60:996-1005.

22 Willadsen SM. 1986. Nuclear transplantation in sheep embryos. Nature 320:63-65. 
1 Wilmut I, Schnieke AE, McWhir J, Kind AJ, Campbell KH. 1997. Viable offspring

2 derived from fetal and adult mammalian cells. Nature 385:810-813.

3 Yang X, Jiang S, Farrell P, Foote RH, McGrath AB. 1993. Nuclear transfer in cattle:

4 Effect of nuclear donor cells, cytoplast age, co-culture, and embryo transfer. Mol

$5 \quad$ Reprod Dev 35:29-36.

6 Zimmermann U, Vienken J. 1982. Electric field-induced cell-to-cell fusion. J Membr

$7 \quad$ Biol 67:165-82.

8 Zou X, Chen Y, Wang Y, Luo J, Zhang Q, Zhang X, Yang Y, Ju H, Shen Y, Lao W, Xu

9 S, Du M. 2001. Production of cloned goats from enucleated oocytes injected with 10 cumulus cell nuclei or fused with cumulus cells. Cloning 3:31-37.

11

12 


\section{ACKNOWLEDGEMENT}

2 We greatly appreciated Shie Jiang for technical assistance; Dr. Michele Barber for

3 cell culture, Sharmeen Jones for manuscript typing, Marina Julian, Drs. Robert H Foote,

4 John J. Orris for their valuable discussion and comments. This study is supported in part

5 by Cornell University Biotechnology Program from the New York State Science and

6 Technology Foundation and a Consortium of Industries. This manuscript is a scientific

7 contribution of the Storrs Experiment Station at the University of Connecticut (no.2077). 
1 Table 1. Development of bovine oocytes following different activation procedures

\begin{tabular}{|c|c|c|c|c|c|c|c|}
\hline Treatment & $\begin{array}{l}\text { No. } \\
\text { rep }\end{array}$ & $\begin{array}{c}\text { Total No. } \\
\text { oocytes }\end{array}$ & $\begin{array}{c}\text { No. }(\%) \\
\text { oocytes lysed }\end{array}$ & $\begin{array}{c}\text { No. of oocytes } \\
\text { cultured* }\end{array}$ & $\begin{array}{l}\text { No. }(\%) \\
\text { cleaved }\end{array}$ & $\begin{array}{c}\text { No. }(\%) \\
\text { BL }\end{array}$ & $\begin{array}{c}\text { \% (overall } \\
\text { BL rate) }\end{array}$ \\
\hline A. A187/EP/CHX/EPx2 & 4 & 134 & $5(4)^{\mathrm{a}}$ & 90 & $48(53)^{\mathrm{a}}$ & $13(14)^{\mathrm{a}}$ & $10^{\mathrm{a}}$ \\
\hline B. EP/EP/CHX/EPx2 & 4 & 156 & $42(27)^{b}$ & 90 & $45(50)^{\mathrm{a}}$ & $7(8)^{\mathrm{a}}$ & $4^{\mathrm{a}, \mathrm{b}}$ \\
\hline C. EP/ETOH/CHX/EPx2 & 4 & 135 & $5(4)^{\mathrm{a}}$ & 90 & $38(42)^{\mathrm{a}}$ & $11(12)^{\mathrm{a}}$ & $8^{\mathrm{a}}$ \\
\hline D. A187/EP90/CHX/CD & 4 & 211 & $80(38)^{b}$ & 90 & $67(74)^{b}$ & $28(31)^{b}$ & $13^{\mathrm{a}}$ \\
\hline E. Control & 4 & 102 & $0(0)^{\mathrm{a}}$ & 102 & $11(11)^{\mathrm{c}}$ & $0^{\mathrm{c}}$ & $0^{\mathrm{b}}$ \\
\hline
\end{tabular}

${ }^{a b c}$ Values with different superscripts within columns differ, $\mathrm{P}<0.05$. A187, calcium ionophore A23187;

$3 \mathrm{CD}$, cytochalasin D; CHX, cycloheximide; EP, electrical pulse; EPx2, two electrical pulses applied;

4 EP90, electrical pulse at $90 \mu \mathrm{sec} ; \mathrm{ETOH}$, ethanol. *The oocytes from each group are selected for further culture experiment, and

5 leftover oocytes are fixed and subjected to morphological evaluation (data not shown). The overall blastocyst rates were

6 calculated using total number of oocytes in each treatment. 
Table 2. Effect of intensity of electric pulse on parthenogenetic development

\begin{tabular}{lccccccc}
\hline Treatment & $\begin{array}{c}\text { No. } \\
\text { rep }\end{array}$ & $\begin{array}{c}\text { Total No. } \\
\text { oocytes }\end{array}$ & $\begin{array}{c}\text { No. }(\%) \\
\text { oocytes lysed }\end{array}$ & $\begin{array}{c}\text { No. of oocytes } \\
\text { cultured }\end{array}$ & $\begin{array}{c}\text { No. (\%) } \\
\text { cleaved }\end{array}$ & $\begin{array}{c}\text { No. (\%) } \\
\text { BL }\end{array}$ & $\begin{array}{c}\% \text { (overall } \\
\text { BL rate) }\end{array}$ \\
\hline A. A187/EP/CHX/CD & 3 & 122 & $13(11)^{\mathrm{a}}$ & 109 & $86(79)^{\mathrm{a}}$ & $36(33)^{\mathrm{a}}$ & $29^{\mathrm{a}}$ \\
B. A187/EP45/CHX/CD & 3 & 122 & $21(17)^{\mathrm{a}}$ & 101 & $74(73)^{\mathrm{a}}$ & $27(27)^{\mathrm{a}}$ & $22^{\mathrm{a}, \mathrm{b}}$ \\
C. A187/EP60/CHX/CD & 3 & 122 & $34(28)^{\mathrm{b}}$ & 88 & $62(70)^{\mathrm{a}}$ & $24(27)^{\mathrm{a}}$ & $20^{\mathrm{b}, \mathrm{c}}$ \\
D. A187/EP90/CHX/CD & 3 & 122 & $51(42)^{\mathrm{c}}$ & 71 & $52(73)^{\mathrm{a}}$ & $15(21)^{\mathrm{a}}$ & $12^{\mathrm{c}, \mathrm{d}}$ \\
E. A187/EP/CHX & 3 & 122 & $2(2)^{\mathrm{d}}$ & 120 & $55(46)^{\mathrm{b}}$ & $11(9)^{\mathrm{b}}$ & $9^{\mathrm{d}}$
\end{tabular}

$3 \mathrm{CD}$, cytochalasin D; CHX, cycloheximide; EP, electrical pulse; EP 45, EP60, and EP90 represent electrical

4 pulse at 45, 60 and $90 \mu \mathrm{sec}$, respectively. The overall blastocyst rates were calculated using total number of oocytes in each

5 treatment.

6 
1 Table 3. Effect of cytochalasins on parthenogenetic development

\begin{tabular}{|c|c|c|c|c|c|c|c|}
\hline Treatment & $\begin{array}{l}\text { No. } \\
\text { rep }\end{array}$ & $\begin{array}{l}\text { Total No. } \\
\text { oocytes }\end{array}$ & $\begin{array}{c}\text { No. (\%) } \\
\text { oocytes lysed }\end{array}$ & $\begin{array}{c}\text { No. of oocytes } \\
\text { cultured }^{*}\end{array}$ & $\begin{array}{l}\text { No. (\%) } \\
\text { cleaved }\end{array}$ & $\begin{array}{c}\text { No. }(\%) \\
\text { BL }\end{array}$ & $\begin{array}{c}\text { \% (overall } \\
\text { BL rate) }\end{array}$ \\
\hline A. A187/EP/CHX/CB5/EPx2 & 5 & 206 & $31(15)^{\mathrm{a}}$ & 139 & $97(70)^{\mathrm{a}}$ & $29(21)^{\mathrm{a}}$ & $14^{\mathrm{a}}$ \\
\hline B.A187/EP/CHX/CB2.5/EPx2 & 5 & 210 & $29(14)^{\mathrm{a}}$ & 142 & $96(68)^{\mathrm{a}}$ & $37(26)^{\mathrm{a}}$ & $17^{\mathrm{a}}$ \\
\hline C. A187/EP/CHX/CD/EPx2 & 5 & 205 & $25(12)^{\mathrm{a}}$ & 141 & $104(74)^{\mathrm{a}}$ & $54(38)^{b}$ & $26^{\mathrm{b}}$ \\
\hline D. A187/EP90/CHX/CD & 5 & 264 & $141(53)^{b}$ & 113 & $84(74)^{\mathrm{a}}$ & $35(31)^{\mathrm{ab}}$ & $13^{\mathrm{a}}$ \\
\hline
\end{tabular}

${ }^{\mathrm{ab}}$ Values within columns with different superscripts differ, $\mathrm{P}<0.05$. A187, calcium ionophore A23187;CB2.5, cytochalasin B at

$2.5 \mu \mathrm{g} / \mathrm{ml}$; CB5, cytochalasin B at $5.0 \mu \mathrm{g} / \mathrm{ml}$; CD, cytochalasin D; CHX, cycloheximide; EP, electrical pulse; EP90, electrical pulse at $90 \mu \mathrm{sec}$. ${ }^{*}$ The oocytes from each group are selected for further culture experiment, and leftover oocytes are fixed and subjected to morphological evaluation (data not shown). The overall blastocyst rates were calculated using total number of oocytes in each treatment. 
1 Table 4. Development of NT embryos with embryonic and somatic donor nuclei

\begin{tabular}{|c|c|c|c|c|c|}
\hline Treatment & $\begin{array}{l}\text { No. } \\
\text { rep }\end{array}$ & $\begin{array}{l}\text { No. of donor } \\
\text { oocyte pairs }\end{array}$ & $\begin{array}{l}\text { No.(\%) of } \\
\text { fused }\end{array}$ & $\begin{array}{l}\text { No. }(\%) \\
\text { cleaved* }\end{array}$ & $\begin{array}{c}\text { No. }(\%) \\
\text { BL* }\end{array}$ \\
\hline $\begin{array}{l}\text { Embryonic donor NT } \\
\text { A. A187/EP/CHX/NT }\end{array}$ & 5 & 233 & $184(79)^{\mathrm{a}}$ & $142(77)^{\mathrm{a}}$ & $66(36)^{\mathrm{a}}$ \\
\hline B. MII/NT/A187/EP/CHX & 5 & 97 & $73(75)^{\mathrm{a}}$ & $37(50)^{b}$ & $8(11)^{b}$ \\
\hline $\begin{array}{l}\text { Somatic donor NT } \\
\text { C. A } 187 / \mathrm{EP} / \mathrm{CHX} / \mathrm{NT}\end{array}$ & 5 & 249 & $107(43)^{\mathrm{b}}$ & $62(58)^{b}$ & $6(6)^{b}$ \\
\hline D. MII/NT/A187/EP/CHX & 5 & 253 & $124(49)^{\mathrm{b}}$ & $94(76)^{\mathrm{a}}$ & $37(30)^{\mathrm{a}}$ \\
\hline \multicolumn{6}{|c|}{${ }^{\mathrm{a}, \mathrm{b}}$ Values within columns with different superscripts differ, $\mathrm{P}<0.05$. A187, calcium ionophore A2318 } \\
\hline
\end{tabular}


Table 5. Analysis of TE/ICM in different types of parthenogenetic and NT blastocysts

\begin{tabular}{ccccc}
\hline $\begin{array}{c}\text { Blastocyst type } \\
\text { (Day 8) }\end{array}$ & $\begin{array}{c}\text { No. of } \\
\text { embryos }\end{array}$ & $\begin{array}{c}\text { Cells/ } \\
\text { BL }\end{array}$ & $\begin{array}{c}\text { No. (\%) ICM } \\
\text { cells }\end{array}$ & $\begin{array}{c}\text { No. (\%) } \\
\text { pycnotic cells }\end{array}$ \\
\hline Parthenogenetic & 12 & $133 \pm 14^{\mathrm{a}}$ & $36 \pm 6(26)^{\mathrm{a}}$ & $9 \pm 1(7)^{\mathrm{a}}$ \\
Embryonic NT & 14 & $142 \pm 18^{\mathrm{a}}$ & $44 \pm 9(29)^{\mathrm{a}}$ & $5 \pm 2(3)^{\mathrm{a}}$ \\
Somatic NT & 12 & $139 \pm 10^{\mathrm{a}}$ & $47 \pm 8(33)^{\mathrm{a}}$ & $4 \pm 2(3)^{\mathrm{a}}$ \\
Frozen in vivo & 7 & $145 \pm 17^{\mathrm{a}}$ & $32 \pm 6(23)^{\mathrm{a}}$ & $9 \pm 3(6)^{\mathrm{a}}$
\end{tabular}

$5 \quad$ NT, nuclear transfer.

6 
2 Fig. 1. Parthenogenetic activation and nuclear transfer in cattle. (A) Bovine oocytes

3 after maturation for $20-22 \mathrm{~h}$ in vitro showed the expansion of cumulus cells. After

4 activation oocytes have undergone development in vitro to compacted morulae (B) at

5 Day 4.5 and expanded blastocysts (C) at Day 8. (D)The inner cell mass (ICM) and

6 trophectoderm (TE) cells were stained blue and pink, respectively, when a

7 parthenogenetic blastocyst was treated with differential staining (arrows indicating

8 pycnotic inner nuclei shown as blue fragments). (E-H) Nuclear transfer of embryonic

9 donor nuclei into pre-activated cytoplasts. Oocytes are enucleated by aspirating the first

10 polar body (arrow) and surrounding cytoplasm containing the metaphase plate $(\mathbf{E})$, then

11 subjected to an activation protocol, followed by insertion of embryonic cells $(\mathbf{F})$ and cell

12 fusion as shown by the arrow in the insert of $(\mathbf{F})$. Fused embryos developed to hatched

13 blastocysts $(\mathbf{G})$ at Day 8 with a proportional allocation of ICM (blue)/TE (pink) cells (H).

14 (I-L) Nuclear transfer of somatic cells into M II cytoplasts. Fibroblasts (I) at passage 5-6

15 were transferred into the perivitelline space of oocytes $(\mathbf{J})$, and after optimal activation

16 fused embryos developed to hatched blastocysts $(\mathbf{K})$ in vitro at 8 days of culture. The

17 resultant blastocysts possessed ICM (blue) and TE (pink) cells (L). Bar=100 $\mu \mathrm{m}$. 